\title{
The effect of consumption of foods that differ in energy density and/or sodium bicarbonate supplementation on subsequent diet selection in sheep
}

\author{
Sarah M. James and Ilias Kyriazakis* \\ Animal Nutrition and Health Department, Animal Biology Division, Scottish Agricultural College, King's Buildings, \\ West Mains Road, Edinburgh EH9 3JG Scotland, UK
}

(Received 14 May 2001 - Revised 17 October 2001 - Accepted 13 January 2002)

\begin{abstract}
The short-term consumption of foods that differed in energy density (ED) and/or $\mathrm{NaHCO}_{3}$ supplementation, on subsequent food intake and diet selection in sheep were measured. Thirty sheep weighing 35.9 (SD 2.89) $\mathrm{kg}$ were used. Two foods were formulated: $\mathrm{H}$ had 11 and L had $8 \mathrm{MJ}$ metabolizable energy/kg fresh matter. Four further foods were formulated by adding either $40 \mathrm{~g} \mathrm{NaHCO} / \mathrm{kg}$ or $16.5 \mathrm{~g} \mathrm{NaCl} / \mathrm{kg}$ to foods $\mathrm{H}$ and $\mathrm{L}$. $\mathrm{NaCl}$ was added to give the same $\mathrm{Na}$ concentration as with $40 \mathrm{~g} \mathrm{NaHCO} / 3 / \mathrm{kg}$ to control for any effects of $\mathrm{Na}$ per se. In a preliminary test, it was found that a $2 \mathrm{~h}$ consumption of food $\mathrm{H}$ supplemented with $\mathrm{NaHCO}_{3}$ could buffer potential impact on the rumen environment of subsequent consumption of food $\mathrm{H}$ alone (as judged by rumen $\mathrm{pH}$ and acid-buffering capacity); however, it was not as effective as the consumption of food L alone in doing so. Each food treatment was offered to one of six groups $(n 5)$ for $2 \mathrm{~h}$ following $16 \mathrm{~h}$ of food deprivation. Sheep were then offered a choice between $\mathrm{H}$ and $\mathrm{L}$ for a further $6 \mathrm{~h}$. Supplementing $\mathrm{H}$ or $\mathrm{L}$ with either $\mathrm{NaHCO}_{3}$ or $\mathrm{NaCl}$ had no significant effect on either intake or diet selection. ED significantly $(P<0 \cdot 01)$ affected intake during the $2 \mathrm{~h}$ single feeding period, with sheep offered $\mathrm{H}$ or $\mathrm{L}$ consuming 540 and 663 (SED 37) g respectively, but had no effect on subsequent intake during the choice period. During the choice period all sheep showed a preference for food $\mathrm{H}$, but sheep previously offered L selected significantly more $\mathrm{H}(0.873 \mathrm{~g} / \mathrm{g})$ than sheep previously offered $\mathrm{H}(0.544$ (SED 0.028) $\mathrm{g} / \mathrm{g} ; P<0.001)$. It is concluded that short-term consumption of foods that differ in ED, and hence in their potential impact on the rumen environment, significantly affects subsequent diet selection. This is in agreement with the hypothesis that ruminant animals select a diet to help maintain the rumen environment within a certain physiological range. Food $\mathrm{H}$ with $40 \mathrm{~g} \mathrm{NaHCO}_{3}$ added/kg may not have been sufficient to affect subsequent diet selection. It is suggested that larger, rather than smaller, changes in the rumen environment achieved through previous feeding should be expected to alter subsequent diet selection.
\end{abstract}

Diet selection: Energy density: Sodium bicarbonate: Sheep

Grazing animals make complex foraging decisions including distinguishing between plant species within the sward and between plant parts within a species. Making such distinctions enables them to select a diet that may meet their nutrient and energy requirements (Illius et al. 1992). It has been suggested by many authors (e.g. Kenney \& Black, 1984; Van Wieren, 1996), and is assumed in foraging models based on the idea of optimality (Charnov, 1975; Belovsky, 1978; Belovsky \& Schmitz, 1994) that animals select a diet that maximizes their rate of energy intake. However, ruminant animals have clearly been seen not to maximize their short-term energy intake rates whilst grazing (Newman et al. 1994; Parsons et al. 1994). In addition, sheep offered a choice between two concentrate foods that differed in their energy density (ED) included a considerable proportion of the low-ED food in their diet (Copper et al. 1995, 1996). These results appear to contradict the energy rate maximization assumption of the optimal foraging theory (Stephens \& Krebs, 1986).

The potentially disruptive effects on the rumen environment, such as a fall in $\mathrm{pH}$, caused by the consumption of a high-ED food that is readily fermentable (Kaufman, 1976),

\footnotetext{
Abbreviations: ED, energy density; H, high-energy-density food; L, low-energy-density food; ME, metabolizable energy; TFI, total food intake.

* Corresponding author: Professor I. Kyriazakis, fax +44 131535 3121, email i.kyriazakis@ed.sac.ac.uk
} 
may account for ruminant animals not foraging in accordance with the optimal foraging theory (Parsons et al. 1994; Cooper et al. 1995, 1996; Kyriazakis et al. 1999). The maintenance of $\mathrm{pH}$ within the rumen is of great importance to resident micro-organisms (Russell et al. 1979) and is of importance to the host (Owens et al. 1998). It has thus been suggested that one of the objectives of the diet selection of ruminant animals might well be to maintain a fit and adaptive rumen (Cooper et al. 1995, 1996; Faverdin, 1999). It could be hypothesized that ruminant animals include a large proportion of low-ED food in their diet in order to dilute the disruptive effects of a high-ED food when they are given a choice. However, including some of the lower ED food into the diet could result in a lower energy intake than when the diet consists solely of the high-ED food (Kyriazakis \& Oldham, 1993; Cooper et al. 1995). Ruminant animals can thus be seen as making a trade-off between the potential benefits of selecting a higher energy food against the potential cost of disrupting the rumen environment, when having to select their diet from two foods that have different effects on the rumen environment (Kyriazakis et al. 1999). Short-term modifications in diet selection could be seen as aiming first to prevent further disruption to the rumen environment after a 'disruptive' food has already been consumed, and second, to return the conditions in the rumen to within an acceptable range as soon as possible.

The objective of the present experiment was to determine the effect of short-term consumption of foods that differ in $\mathrm{ED}$ and/or $\mathrm{NaHCO}_{3}$ supplementation on subsequent food intake and diet selection in sheep. We hypothesized that the extent of subsequent selection for the low-ED food, when sheep are offered a choice between a high- and low-energy food, would depend on prior consumption of such foods. We expected that animals that have consumed a high-ED food would select a diet with a higher proportion of the low-ED food and vice versa. Addition of $\mathrm{NaHCO}_{3}$, which has the potential to act as a buffer, to the high-ED food consumed singly, the food consumed previously, would be expected to reverse such diet selection.

\section{Materials and methods}

\section{Animals and housing}

Thirty Texel $\times$ Greyface wether sheep, approximately 1 year of age and weighing 35.9 (SD 2.89) $\mathrm{kg}$ at the start of the experiment were used. They had previously been housed as groups and fed hay of medium quality ad libitum. They were kept in individual raised pens $(2.0 \times$ $1.5 \mathrm{~m}$ ) in a shed that was naturally ventilated. Throughout the experiment artificial lighting was provided from 06.00 to 18.00 hours but, as the experiment was carried out during March-May 1998 at latitude $56^{\circ} \mathrm{N}$, the duration of daylight had the potential to be longer than the period of artificial lighting. The sheep were given $21 \mathrm{~d}$ acclimatization to allow them to become accustomed to their new environment and experimental procedures before the start of the experiment. They were offered a high quality pelleted food with $184 \mathrm{~g}$ crude protein $(\mathrm{N} \times 6 \cdot 25) \mathrm{kg} \mathrm{DM}$ and $10 \mathrm{MJ}$ metabolizable energy (ME)/kg DM ad libitum with no access to long forage. All sheep had free and continuous access to water throughout.

\section{Experimental foods}

Two basal foods, $\mathrm{H}$ and $\mathrm{L}$, that differed in ED were formulated (Table 1). Food $\mathrm{H}$ was designed to at least meet the metabolizable protein and ME requirements of sheep of $36 \mathrm{~kg}$ live weight for potential growth (Agricultural and Food Research Council, 1993). Food L was designed to be deficient in energy content to support potential growth when offered alone on an ad libitum basis. Food L was made by diluting $\mathrm{H}$ with oatfeed, a much less digestible material. It was expected that $\mathrm{L}$ would be fermented more slowly than H (Ministry of Agriculture, Fisheries and Food, 1990) and therefore would be potentially less disruptive to the rumen environment. The metabolizable

Table 1. Ingredients, determined chemical analyses, calculated yields of metabolizable energy and protein components of the two basal experimental foods

\begin{tabular}{|c|c|c|}
\hline & \multicolumn{2}{|c|}{ Foods } \\
\hline & $\mathrm{H}$ & L \\
\hline \multicolumn{3}{|l|}{ Ingredients (g/kg) } \\
\hline Barley & 411 & 120 \\
\hline Oatfeed & 40 & 572 \\
\hline Citrus pulp & 300 & 71 \\
\hline Soyabean meal (solvent extracted) & 155 & 148 \\
\hline Fat premix $(500 \mathrm{~g} / \mathrm{kg})^{*}$ & 25 & 25 \\
\hline Molasses & 50 & 50 \\
\hline Salt & $6 \cdot 8$ & 4.0 \\
\hline Dicalcium phosphate & 3.5 & $1 \cdot 2$ \\
\hline Limestone flour & $6 \cdot 0$ & 5.9 \\
\hline Calcified magnesite & 0.1 & 0.4 \\
\hline Vitamin and mineral mix $\dagger$ & 2.5 & 2.5 \\
\hline Total & 1000 & 1000 \\
\hline \multicolumn{3}{|l|}{ Chemical analysis ( $\mathrm{g} / \mathrm{kg} \mathrm{DM}$ ) } \\
\hline $\mathrm{DM}(\mathrm{g} / \mathrm{kg})$ & 874 & 887 \\
\hline Crude protein & 158 & 117 \\
\hline Crude fibre & 89 & 185 \\
\hline Modified acid-detergent fibre & 137 & 278 \\
\hline Neutral-detergent fibre & 226 & 475 \\
\hline Ash & 71 & 69 \\
\hline Calcium & 9.3 & $6 \cdot 6$ \\
\hline Phosphorus & 4.0 & 2.9 \\
\hline Sodium & 3.4 & 2.5 \\
\hline Sulfur & 1.9 & 1.8 \\
\hline \multicolumn{3}{|l|}{ Estimated yields $\ddagger$} \\
\hline $\mathrm{ME}(\mathrm{MJ} / \mathrm{kg} \mathrm{DM}) \S$ & $12 \cdot 7$ & $9 \cdot 0$ \\
\hline Fermentable ME (MJ/kg DM) & $11 \cdot 7$ & 8.0 \\
\hline MP (g/kg DM) & 101.9 & 74.5 \\
\hline eRDP (g/kg DM) & 114.3 & $80 \cdot 0$ \\
\hline MP:ME (g/MJ) & 8.0 & $8 \cdot 3$ \\
\hline eRDP:fermentable ME (g/MJ) & $9 \cdot 8$ & $10 \cdot 0$ \\
\hline
\end{tabular}

ME, metabolizable energy; MP, metabolizable protein; eRDP, effective rumen degradable protein.

* Manufactured and supplied by Central Farmers Ltd, Methil, Fife, Scotland, UK.

†Vitamin and mineral mix used was Scotmin ewe/lamb (Scotmin Nutrition Ltd, Ayr, Scotland).

$\ddagger$ Values calculated using the MP system (Agricultural and Food Research Council, 1993) assuming rumen outflow rate of $0.05 \mathrm{~h}^{-1}$ and standard values for degradability coefficients (Ministry of Agriculture, Fisheries and Food, 1990).

$\S \mathrm{ME}$ calculated from food tables (Ministry of Agriculture, Fisheries and Food, 1990). 
protein:ME, effective rumen degradable protein:fermentable $\mathrm{ME}$ and minerals:ME ratios were kept as similar as possible in $\mathrm{L}$ and $\mathrm{H}$. This was done in order that the selection made by sheep offered a choice between the two foods could be interpreted on an energy-content basis (Cooper et al. 1994).

Five additional foods were formulated by adding 10, 20, 40 or $80 \mathrm{~g} \mathrm{NaHCO}_{3} / \mathrm{kg}$ fresh matter to $\mathrm{H}\left(\mathrm{H}_{10}, \mathrm{H}_{20}, \mathrm{H}_{40}\right.$ and $\mathrm{H}_{80}$ respectively) and $40 \mathrm{~g} \mathrm{NaHCO}_{3} / \mathrm{kg}$ fresh matter to $\mathrm{L}$ $\left(\mathrm{L}_{40}\right) . \mathrm{NaHCO}_{3}$ was selected for this experiment because many studies have previously shown that $\mathrm{NaHCO}_{3}$ is an effective dietary buffer for ruminant animals when added to foods of low-fibre and high-energy content (Ha et al. 1983; Hart \& Polan, 1984). It was expected that $\mathrm{NaHCO}_{3}$ would have beneficial effects on the rumen environment by reducing the decline in $\mathrm{pH}$ when $\mathrm{H}$ was consumed. Two further foods were formulated by adding $16.5 \mathrm{~g} \mathrm{NaCl} / \mathrm{kg}$ fresh matter to $\mathrm{H}$ and $\mathrm{L}\left(\mathrm{H}_{\mathrm{NaCl}}\right.$ and $\mathrm{L}_{\mathrm{NaCl}}$ respectively). $\mathrm{NaCl}$ was added to both foods to provide the same concentration of $\mathrm{Na}$ that would result from adding $40 \mathrm{~g} \mathrm{NaHCO}_{3} / \mathrm{kg}$, to control for the effects of $\mathrm{Na}$ per se (Carter \& Grovum, 1990).

\section{Experimental design}

Test A. The two foods used in this 2 -week test were the two basal foods $\mathrm{H}$ and $\mathrm{L}$. The sheep were allocated to one of two groups ( $n$ 15), taking into account their live weight at this point, so that the mean live weight of each group was similar (35.9 (SD 1.68) $\mathrm{kg}$ ). One group was offered a choice between foods $\mathrm{L}$ and $\mathrm{H}$ from 09.00 to 17.00 hours daily. The other group was offered the same choice of foods continuously. The positions of the two foods within a pen were randomized within group, but their positions were not changed during the testing period.

The test was performed to determine: (1) whether sheep in our experimental conditions do select between a highand low-ED food in a manner consistent with the idea of a trade-off and include substantial amounts of food $\mathrm{L}$ in their diet; (2) the effect of offering foods for a period of $8 \mathrm{~h}$ instead of $24 \mathrm{~h}$ daily on diet selection between two foods that differed in ED. An $8 \mathrm{~h}$ feeding period was required to increase feeding motivation in tests $B$ and $C$ to ensure that the treatment foods offered were consumed (see later).

Test $B$. The six foods used in this test were the two basal food, $\mathrm{H}$ and $\mathrm{L}$, and food $\mathrm{H}$ supplemented with $\mathrm{NaHCO}_{3}\left(\mathrm{H}_{10}, \mathrm{H}_{20}, \mathrm{H}_{40}\right.$ and $\left.\mathrm{H}_{80}\right)$. The test lasted for a period of $11 \mathrm{~d}$. Sheep were allocated to one of six groups ( $n$ 5) in accordance with their live weight at this point, so that the mean live weights of each group at the beginning of the test were similar (40.6 (SD 2.88) $\mathrm{kg})$. Groups 1-6 were offered one of: $\mathrm{H}, \mathrm{H}_{10}, \mathrm{H}_{20}, \mathrm{H}_{40}, \mathrm{H}_{80}$ or $\mathrm{L}$, the treatment foods, for a period of $2 \mathrm{~h}$ from 09.00 to 11.00 hours. At 11.00 hours all refusals were removed and weighed and all sheep were offered food $\mathrm{H}$ alone until 17.00 hours, when all foods were removed.

This test was carried out to determine how disruptive the two ED foods used in this experiment were on the rumen environment after they had been offered for $2 \mathrm{~h}$ and what concentration of $\mathrm{NaHCO}_{3}$ should be added to food $\mathrm{H}$ to obtain the most beneficial combined effects on rumen $\mathrm{pH}$ and intake, when offered for a $2 \mathrm{~h}$ period. It has been demonstrated that the buffering effects of $\mathrm{NaHCO}_{3}$ added to a food are greatest $2-8 \mathrm{~h}$ after initial consumption (Erdman, 1988). For this reason the foods containing the $\mathrm{NaHCO}_{3}$, along with foods $\mathrm{H}$ and $\mathrm{L}$ for comparison, were offered for a period of $2 \mathrm{~h}$, the minimum time suggested before the effects of $\mathrm{NaHCO}_{3}$ supplementation were greatest. Measurements of subsequent intake were collected for a further $6 \mathrm{~h}$ after the treatment foods had been removed.

Rumen content samples were collected via a stomach tube every $2 \mathrm{~h}$ from 09.00 to 17.00 hours inclusively on every alternate day starting on day 1 . The $2 \mathrm{~h}$ sampling times were selected as these coincided with the measurements collected on food intake. A $2 \mathrm{~h}$ collection period was also relevant to $\mathrm{pH}$ as it was predicted that the $\mathrm{pH}$ of the rumen environment at 11.00 hours, when treatment foods were removed, would influence subsequent intake. Each sheep within a group was sampled once per day but the time of sampling changed on each of the sampling days. This resulted in each sheep being sampled at each of the sampling times by the end of the test, with the sequence of the samples on day 1 being repeated on day 11.

The $\mathrm{pH}$ of the rumen samples was measured immediately after collection using a glass electrode (Model RL 250/pH/ISE meter; Russell Laboratories Ltd, Auchtermuchty, Fife, Scotland, UK). The rumen samples were then strained through double-thickness muslin and treated with $250 \mu \mathrm{l}$ saturated mercuric chloride prior to freezing for subsequent analysis of $\mathrm{NH}_{3}-\mathrm{N}$ concentration using an ion-selective electrode (Model 95-5129, Russell Laboratories Ltd).

The in vitro acid-buffering capacity of the strained rumen content samples was measured using a modification of the procedure by Jasaitis et al. (1987). A $5 \mathrm{ml}$ rumen sample was suspended in $50 \mathrm{ml}$ distilled deionized water and stirred continuously with a magnetic stir bar. Titrations were performed by the addition of acid $(0 \cdot 1 \mathrm{M}-\mathrm{HCl})$ until the $\mathrm{pH}$ was decreased to 4 . Acid-buffering capacity was calculated by dividing titratable acidity (total volume of acid added to each sample multiplied by its molarity) by the total change in concentration of hydrogen ions $\left(\left[\mathrm{H}^{+}\right]=\right.$ $10 \times(\exp (-\mathrm{pH})))$. The base-buffering capacity of the rumen samples was not measured in this experiment as the rumen $\mathrm{pH}$ seldom exceeds 7 , especially when high energy, readily fermentable concentrate foods are offered (Erdman, 1988).

Test $C$. The six foods used in this test were the two basal foods, $\mathrm{H}$ and $\mathrm{L}$, and these foods supplemented with either $40 \mathrm{~g} \quad \mathrm{NaHCO}_{3} / \mathrm{kg}\left(\mathrm{H}_{40}\right.$ and $\left.\mathrm{L}_{40}\right)$ or with $16.5 \mathrm{~g}$ $\mathrm{NaCl} / \mathrm{kg}\left(\mathrm{H}_{\mathrm{NaCl}}\right.$ and $\left.\mathrm{L}_{\mathrm{NaCl}}\right)$. Test $\mathrm{C}$ lasted for a period of $21 \mathrm{~d}$, a length of time expected to be sufficient for any pattern in subsequent diet selection to be observed (Cooper et al. 1996). Sheep were allocated to one of six groups ( $n$ 5) such that the live weights of each group at the beginning of the test were similar (41.2 (SD 1.36) $\mathrm{kg}$ ). Groups 1 to 6 were offered one of: $\mathrm{H}, \mathrm{H}_{40}, \mathrm{H}_{\mathrm{NaCl}}$, $\mathrm{L}, \mathrm{L}_{40}$, or $\mathrm{L}_{\mathrm{NaCl}}$ for a period of $2 \mathrm{~h}$ from 09.00 to 11.00 hours. At 11.00 hours all refusals were removed and 
weighed and all sheep were offered $\mathrm{H}$ and $\mathrm{L}$ as a choice until 17.00 hours, when all foods were removed. The position of the two foods within a pen, offered as a choice, were randomized within treatment. The position was not changed during the testing period. When only one food was offered the food trough was in a position central to the choice positions. This test was designed to address the main objective of the experiment, which was to determine the effect of consumption of foods that differ in ED and/or $\mathrm{NaHCO}_{3}$ supplementation on subsequent diet selection in sheep.

\section{Measurements}

The weights of all food troughs containing fresh food were recorded at 09.00 hours and food then offered to the sheep each day. At $2 \mathrm{~h}$ intervals, from 09.00 to 17.00 hours inclusively, food intake was recorded by removing the food troughs, weighing them with their contents and returning them to the pens. The amount consumed was then calculated by subtracting the weight of the trough with its contents from the previous weight recorded. The live weights of the sheep were measured on the first day of each test, then weekly thereafter, with tests conducted consecutively.

Samples of all foods offered were taken every week and a composite sample was analysed for DM, crude protein $(\mathrm{N} \times 6.25)$ neutral-detergent (plus amylase) fibre, aciddetergent fibre, $\mathrm{Na}, \mathrm{Ca}$ and $\mathrm{P}$ contents as described by the Ministry of Agriculture, Fisheries and Food (1993) (Table 1).

\section{Statistical analysis}

All data were analysed using GENSTAT for Windows, version 5.2 (1993; Lawes Agricultural Trust, Rothamsted, Herts., UK) unless otherwise stated. The diet selection data (expressed as the proportion of food intake taken as food $\mathrm{H}$ ) were normally distributed and were not transformed for further analysis. Where appropriate, a Student's $t$ test with a null hypothesis of mean 0.5 for each group was used to test whether the proportion of food selected differed from random (Minitab for Windows, release 11.1, 1996; Minitab Inc., State College, PA, USA).

Test $A$. The data for total food intake (TFI) and diet selection for each $2 \mathrm{~h}$ interval, and daily, were analysed using one-way ANOVA. To determine whether there was a time interval effect on intake and diet selection, data from each time interval for each group from 09.00 to 17.00 hours were treated as repeated measures and analysed as a split-plot design where time interval was the sub-plot factor, nested within sheep. For each sheep the linear regression coefficient for weight on time over the 2 weeks was used to estimate live-weight gain. The rate of gain and food conversion efficiency ( $g$ weight gained/kg food eaten) were analysed using one-way ANOVA.

Test $B$. The data for TFI for each individual $2 \mathrm{~h}$ interval and daily (09.00-17.00 hours) were analysed using one-way ANOVA. Data collected from rumen content samples were analysed using Residual Maximum Likelihood (REML) due to the unbalanced nature of the data.
Wald tests on $\mathrm{pH}, \mathrm{NH}_{3}-\mathrm{N}$ and acid-buffering capacity are obtained from the REML procedure and were used to determine any significant differences present using the degrees of freedom and probability value for the fixed effect (group) provided by REML (1993; Lawes Agricultural Trust).

Test $C$. TFI and diet selection data for each $2 \mathrm{~h}$ interval, over the choice period, and each day where appropriate, were analysed as a $2 \times 3$ factorial design using ANOVA. Effects of, and interactions between, ED ( $\mathrm{H}$ or $\mathrm{L}$ ) and supplement (none, $\mathrm{NaHCO}_{3}$ or $\mathrm{NaCl}$ ) were analysed with $\mathrm{ED}$ and supplement as factors. These data for each group, over the choice period (11.00-17.00 hours), were also subjected to repeated-measures analysis as a split-plot design (see test A) to determine whether there was an effect of time on food intake and diet selection. For each sheep the linear regression coefficient for weight $v$. time, over the 3 weeks was used to estimate live-weight gain. The rate of gain and food conversion efficiency were analysed as a $2 \times$ 3 factorial design as described earlier.

\section{Results \\ Test A}

Results for test A are given in Table 2. TFI was significantly greater $(P<0.05)$ for sheep offered the foods for $24 \mathrm{~h}$ continuously. However, sheep offered food for $8 \mathrm{~h} / \mathrm{d}$ consumed significantly more $(P<0.001)$ during three, out of the four, $2 \mathrm{~h}$ intervals than those offered foods for $24 \mathrm{~h}$. Daily food intake significantly $(P<0.001)$ increased from week 1 to week 2 of the test for both groups with no interaction between week and group. There was a significant effect of time interval $(P<0.05)$ on the amount of food consumed. The amount of food consumed by the sheep offered food for $8 \mathrm{~h} / \mathrm{d}$ was significantly greater $(P<0.05)$ between 09.00 and 11.00 hours than that consumed during any other $2 \mathrm{~h}$ period; the amount consumed during the following $2 \mathrm{~h}$ period (11.00 to 13.00 hours) was significantly less $(P<0.05)$ than that consumed during any other $2 \mathrm{~h}$ period. The only time interval effect on food consumption between 09.00 and 17.00 hours by sheep offered food continuously was that the amount consumed between 11.00 and 13.00 hours was significantly less $(P<0.05)$ than that consumed between 09.00 and 11.00 and between 15.00 and 17.00 hours.

The overall proportion of food $\mathrm{H}$ in the diet selected was significantly greater $(P<0.05)$ for the sheep offered food continuously and it increased significantly $(P<0.001)$ from week 1 to week 2 for both groups. The proportion of food $\mathrm{H}$ selected from 09.00 to 15.00 hours was consistently higher for sheep offered food continuously, though not significantly. However, between 15.00 and 17.00 hours the difference in the proportion of food $\mathrm{H}$ selected by the two groups was significant $(P<0 \cdot 05)$. There was no effect of time interval on the proportion of food $\mathrm{H}$ selected by either of the two groups.

Intake of ME differed significantly $(P<0 \cdot 01)$ between groups: 14.22 and 16.53 (SED 0.660) $\mathrm{MJ} / \mathrm{d}$ for sheep offered food for $8 \mathrm{~h} / \mathrm{d}$ and continuously respectively. Similarly, live-weight gain $(P<0.01)$ and feed conversion 
Table 2. Total food intake and the proportion of food $\mathrm{H}$ selected $(\mathrm{g} / \mathrm{g})$ during each $2 \mathrm{~h}$ interval and daily, and the daily metabolizable energy (ME) intake of sheep offered a choice between two foods that differed in energy density† either for a period of 8 or $24 \mathrm{~h} / \mathrm{d}$ over a 2 week period (test A)‡

(Mean values for fifteen sheep per group)

\begin{tabular}{|c|c|c|c|c|}
\hline & \multicolumn{2}{|c|}{ Food availability } & \multirow[b]{2}{*}{ SED } & \multirow{2}{*}{$\begin{array}{c}\text { Statistical significance } \\
\text { of effect }\end{array}$} \\
\hline & $8 \mathrm{~h}$ & $24 \mathrm{~h}$ & & \\
\hline \multicolumn{5}{|l|}{ Total food intake $(\mathrm{g})$} \\
\hline $09.00-11.00$ hours & 683 & 208 & $32 \cdot 3$ & $\star \star \star *$ \\
\hline $11.00-13.00$ hours & 192 & 166 & 14.4 & NS \\
\hline $13.00-15.00$ hours & 315 & 196 & $12 \cdot 6$ & $* * *$ \\
\hline $15.00-17.00$ hours & 365 & 228 & $18 \cdot 0$ & $* \star *$ \\
\hline $17.00-09.00$ hours & NA & 930 & NA & NA \\
\hline SED & 24.4 & $16 \cdot 8$ & & \\
\hline Daily food intake $(\mathrm{g} / \mathrm{d})$ & 1555 & 1728 & $75 \cdot 6$ & * \\
\hline \multicolumn{5}{|l|}{ Proportion of $\mathrm{H}$ selected $(\mathrm{g} / \mathrm{g})$} \\
\hline $09.00-11.00$ hours & $0.357 \S$ & 0.452 & 0.071 & NS \\
\hline $11.00-13.00$ hours & 0.429 & 0.528 & 0.079 & NS \\
\hline $13.00-15.00$ hours & $0.417 \S$ & 0.528 & 0.070 & NS \\
\hline $15.00-17.00$ hours & $0.407 \S$ & 0.543 & 0.068 & * \\
\hline $17.00-09.00$ hours & NA & 0.573 & NA & NA \\
\hline SED & 0.056 & 0.085 & & \\
\hline Daily proportion of $\mathrm{H}$ selected $(\mathrm{kg} / \mathrm{kg})$ & $0.387 \S$ & 0.536 & 0.069 & * \\
\hline
\end{tabular}

NA, not applicable.

${ }^{\star} P<0.05,{ }^{\star * *} P<0.001$.

†Food H 11MJ ME/kg, Food L 8MJ ME/kg (for details of food see Table 1).

$\ddagger$ For details of procedures, see p. 83.

Mean values were significantly different from random: $\S P<0.05$.

efficiency $(P<0 \cdot 05)$ differed significantly between groups: 291 and 397 (SED 31.7) g/d and 188 and 233 (SED 18.8) g gained/kg food for sheep offered food for 8 and $24 \mathrm{~h}$ daily respectively.

\section{Test $B$}

TFI of the treatment foods (09.00-11.00 hours), food $\mathrm{H}$ (11.00 to 17.00 hours) and daily food intake (09.00 to 17.00 hours) for each of the six groups of sheep offered different treatment foods in test B are shown in Table 3. There was a dose response to the supplementation of $\mathrm{NaHCO}_{3}$ to food $\mathrm{H}$ on food intake during the $2 \mathrm{~h}$ period that the treatment foods were offered (09.00-11.00 hours). This response was significantly quadratic $(P<0.05)$. Intake of sheep offered $\mathrm{H}$, supplemented or unsupplemented, was significantly $(P<0 \cdot 01)$ lower than that of sheep offered $\mathrm{L}$ during the $2 \mathrm{~h}$ period.

As the amount of $\mathrm{NaHCO}_{3}$ increased from 0 to $80 \mathrm{~g} / \mathrm{kg}$ in the treatment foods offered from 09.00 to 11.00 hours, the subsequent amount of the $\mathrm{H}$ food consumed from 11.00 to 17.00 hours also increased. This increase was significant and essentially linear $(P<0 \cdot 01)$ for every $2 \mathrm{~h}$ period interval. Sheep offered $\mathrm{H}$ as a treatment food had a significantly lower intake between 11.00 and 17.00 hours, as well as per d, than any other group. This resulted

Table 3. Total food intake during each $2 \mathrm{~h}$ interval and daily, and the daily metabolizable energy (ME) intake of sheep offered one of the basal foods $\mathrm{H}$ or $\mathrm{L} \dagger$ or $\mathrm{H}$ supplemented with $10\left(\mathrm{H}_{10}\right), 20\left(\mathrm{H}_{20}\right), 40\left(\mathrm{H}_{40}\right)$ or $80\left(\mathrm{H}_{80}\right)$ g NaHCO$/ \mathrm{kg}$ between 09.00 and 11.00 hours followed by food $\mathrm{H}$ unsupplemented for a further $6 \mathrm{~h}$ (test $\mathrm{B}) \ddagger$

(Mean values for five sheep per group)

\begin{tabular}{|c|c|c|c|c|c|c|c|c|}
\hline & \multicolumn{6}{|c|}{ Treatment } & \multirow[b]{2}{*}{ SED } & \multirow{2}{*}{$\begin{array}{c}\text { Statistical significance } \\
\text { of effect }\end{array}$} \\
\hline & $\mathrm{H}$ & $\mathrm{H}_{10}$ & $\mathrm{H}_{20}$ & $\mathrm{H}_{40}$ & $\mathrm{H}_{80}$ & L & & \\
\hline \multicolumn{9}{|l|}{ Treatment food (g) } \\
\hline $\begin{array}{l}09.00-11.00 \text { hours } \\
H \text { food }(\mathrm{g})\end{array}$ & 305 & 399 & 409 & 398 & 317 & $769 \S$ & $72 \cdot 5$ & $\star \star \star *$ \\
\hline $11.00-13.00$ hours & 131 & 160 & $253 \S$ & 242 & $329 \S$ & $306 \S$ & $56 \cdot 8$ & * \\
\hline $13.00-15.00$ hours & 134 & $207 \S$ & $223 \S$ & $234 \S$ & $245 \S$ & $262 \S$ & $26 \cdot 5$ & ** \\
\hline $15.00-17.00$ hours & 158 & $242 \S$ & $263 \S$ & $244 \S$ & $289 \S$ & $317 \S$ & $30 \cdot 1$ & $\star \star \star *$ \\
\hline $11.00-17.00$ hours & 423 & $609 \S$ & $739 \S$ & $720 \S$ & $862 \S$ & $885 \S$ & $88 \cdot 8$ & *** \\
\hline Daily food intake (g/d) & 728 & $1007 \S$ & $1148 \S$ & $1118 \S$ & $1179 \S$ & $1654 \S$ & $106 \cdot 6$ & $* \star *$ \\
\hline Daily ME intake (MJ/d) & 8.0 & $11 \cdot 1 \S$ & $12 \cdot 6 \S$ & $12 \cdot 3 \S$ & $13 \cdot 0 \S$ & $15 \cdot 9 \S$ & $1 \cdot 13$ & $* \star \star$ \\
\hline
\end{tabular}

${ }^{\star} P<0.05,{ }^{\star *} P<0.01,{ }^{* \star *} P<0.001$.

†Food $\mathrm{H} 11 \mathrm{MJ} / \mathrm{kg}$, food $\mathrm{L} 8 \mathrm{MJ} / \mathrm{kg}$ (for details of foods see Table 1).

‡For details of procedures, see p. 83.

Mean values were significantly different from the corresponding value for treatment $\mathrm{H}$ alone: $\S P<0.05$. 
Table 4. The $\mathrm{pH}$ and acid-buffering capacity $(\mathrm{ABC})$ of rumen contents samples collected at each $2 \mathrm{~h}$ interval from 09.00 to $17.00 \mathrm{hours}$ inclusively, from sheep offered one of two basal foods $\mathrm{H}$ or L† or basal food $\mathrm{H}$ supplemented with $10\left(\mathrm{H}_{10}\right), 20\left(\mathrm{H}_{20}\right), 40\left(\mathrm{H}_{40}\right)$ or $80\left(\mathrm{H}_{80}\right) \mathrm{g}$ $\mathrm{NaHCO}_{3} / \mathrm{kg}$ between 09.00 and 11.00 hours followed by food $\mathrm{H}$ unsupplemented for a further $6 \mathrm{~h}$ (test $\mathrm{B}$ ) $\ddagger$

(Mean values for five sheep per group)

\begin{tabular}{|c|c|c|c|c|c|c|c|c|c|c|}
\hline \multirow[b]{3}{*}{ Treatment } & \multicolumn{10}{|c|}{ Sampling time } \\
\hline & \multicolumn{2}{|c|}{09.00 hours } & \multicolumn{2}{|c|}{11.00 hours } & \multicolumn{2}{|c|}{13.00 hours } & \multicolumn{2}{|c|}{15.00 hours } & \multicolumn{2}{|c|}{17.00 hours } \\
\hline & $\mathrm{pH}$ & $A B C(e q) \S$ & $\mathrm{pH}$ & $\mathrm{ABC}(\mathrm{eq}) \S$ & $\mathrm{pH}$ & $\mathrm{ABC}(\mathrm{eq}) \S$ & $\mathrm{pH}$ & $A B C(e q) \S$ & $\mathrm{pH}$ & $A B C(e q) \S$ \\
\hline $\mathrm{H}$ & $7 \cdot 18$ & 3.53 & $5 \cdot 28$ & 2.96 & $5 \cdot 54$ & 2.55 & $5 \cdot 33$ & $2 \cdot 77$ & $5 \cdot 37$ & 1.91 \\
\hline $\mathrm{H}_{10}$ & 7.51 & 3.75 & 5.35 & $2 \cdot 76$ & $5 \cdot 62$ & $2 \cdot 88$ & 5.47 & 3.51 & $5 \cdot 33$ & $3 \cdot 84$ \\
\hline $\mathrm{H}_{20}$ & $7 \cdot 26$ & 3.91 & $5 \cdot 70$ & $2 \cdot 84$ & 5.54 & 3.09 & 5.58 & 2.92 & $5 \cdot 28$ & 3.58 \\
\hline $\mathrm{H}_{40}$ & 7.04 & 3.63 & 5.77 & 3.01 & $5 \cdot 63$ & $3 \cdot 16$ & 5.58 & 3.41 & $5 \cdot 27$ & 3.31 \\
\hline $\mathrm{H}_{80}$ & $7 \cdot 22$ & 3.99 & $6 \cdot 16$ & 2.84 & 5.69 & 3.61 & $5 \cdot 59$ & $3 \cdot 15$ & $5 \cdot 20$ & 2.79 \\
\hline L & 7.21 & $3 \cdot 26$ & 6.05 & 3.53 & 5.95 & 3.56 & $5 \cdot 90$ & 3.55 & $5 \cdot 36$ & 3.09 \\
\hline Mean & $7 \cdot 24$ & 3.68 & $5 \cdot 72$ & 2.99 & $5 \cdot 66$ & $3 \cdot 14$ & $5 \cdot 58$ & $3 \cdot 22$ & $5 \cdot 30$ & 3.09 \\
\hline SED & 0.20 & 1.95 & 0.26 & 1.45 & 0.25 & 1.45 & 0.32 & 1.54 & 0.16 & 1.76 \\
\hline Statistical significance of effect & NS & NS & ** & NS & NS & NS & NS & NS & NS & NS \\
\hline
\end{tabular}

eq, equivalents.

†Food $\mathrm{H} 11 \mathrm{MJ} / \mathrm{kg}$, food L $8 \mathrm{MJ} / \mathrm{kg}$ (for details of foods, see Table 1).

$\ddagger$ For details of procedures, see p. 83.

$\S \mathrm{HCl}$ eq required to lower one unit of $\left[\mathrm{H}^{+}\right]$of $5 \mathrm{ml}$ rumen contents suspended in $50 \mathrm{ml}$ distilled deionized water to $10^{-4}$ (pH 4 ), divided by total in $\left[\mathrm{H}^{+}\right]$change (initial concentration minus $\left.10^{-4}(\mathrm{pH} 4)\right)$. ${ }^{\star \star} P<0.01$.

in their ME intakes being significantly lower than that of any other group. Sheep offered food L as a treatment food consumed significantly more per d than any other group and had a significantly greater ME intake (Table 3 ).

The $\mathrm{pH}$ and acid-buffering capacity of rumen samples collected at each $2 \mathrm{~h}$ interval from 09.00 to 17.00 hours inclusively, for each of the six groups of sheep offered different treatment foods in test $\mathrm{B}$, are shown in Table 4 . As the amount of $\mathrm{NaHCO}_{3}$ supplementation increased from 0 to $80 \mathrm{~g} / \mathrm{kg}$ in the treatment foods offered from 09.00 to 11.00 hours, the $\mathrm{pH}$ of rumen samples collected at 11.00 hours also increased. This increase was significant and essentially linear $(P<0 \cdot 001)$. The consumption of food $\mathrm{L}$ during 09.00 to 11.00 hours did not result in a $\mathrm{pH}$ decline to the same extent as that recorded from sheep that were offered food $\mathrm{H}$ from 09.00 to 11.00 hours. The $\mathrm{pH}$ recorded during all subsequent sampling times $(13.00,15.00$ and 17.00 hours) did not differ significantly between groups. There was no effect of the treatment food offered from 09.00 to 11.00 hours, or sample time on the acid-buffering capacity of the rumen samples. However, the acid-buffering capacity of food $\mathrm{H}$ from 11.00 hours onwards was always lower than that measured from sheep offered $\mathrm{H}$ supplemented with $40 \mathrm{~g} \mathrm{NaHCO}_{3} / \mathrm{kg}$ as a treatment food. Sheep offered $\mathrm{H}$ supplemented with $40 \mathrm{~g} \mathrm{NaHCO}_{3} / \mathrm{kg}$ in turn had a lower acid-buffering capacity at sampling times $11.00,13.00$ and 15.00 hours than that measured from sheep offered food L as a treatment food from 09.00 to 11.00 hours.

$\mathrm{NH}_{3}-\mathrm{N}$ concentrations measured at any sampling time did not differ significantly between groups. The concentration of $\mathrm{NH}_{3}-\mathrm{N}$ did however decrease significantly from the first sample time to the second for all groups (mean $\mathrm{NH}_{3}-\mathrm{N}$ concentration at 09.00 and 11.00 hours was 192 and 136 (SED 12.6) $\mathrm{mg} / \mathrm{l}$ respectively). There was no further effect of time on $\mathrm{NH}_{3}-\mathrm{N}$ concentration.

Combining the effects of $\mathrm{NaHCO}_{3}$ supplementation on food intake between 09.00 and 11.00 hours, when these foods were offered, with the $\mathrm{pH}$ and acid-buffering capacity at 11.00 hours when treatment foods were removed, $40 \mathrm{~g} \mathrm{NaHCO}_{3} / \mathrm{kg}$ was superior to all other $\mathrm{NaHCO}_{3}$ concentrations and hence used for test C.

\section{Test $C$}

TFI during each $2 \mathrm{~h}$ interval and daily are given in Table 5 . ED had a significant effect on intake between 09.00 and 11.00 hours. Overall, sheep offered the L basal food consumed significantly $(P<0.01)$ more than sheep offered the $\mathrm{H}$ basal food during this time period. There was no significant effect of $\mathrm{NaHCO}_{3}$ or $\mathrm{NaCl}$ supplementation on food intake nor were there any significant interactions between ED and supplementation on food intake between 09.00 and 11.00 hours. Neither ED nor $\mathrm{NaHCO}_{3}$ nor $\mathrm{NaCl}$ supplementation had a significant effect on the subsequent TFI between 11.00 and 17.00 hours. Daily food intake did not differ significantly between groups.

$\mathrm{NaHCO}_{3}$ or $\mathrm{NaCl}$ additions to foods offered between 09.00 and 11.00 hours had no significant effect on subsequent diet selection, irrespective of the food to which they were added. Results for groups offered the same basal food, irrespective of supplementation between 09.00 and 11.00 hours, were pooled for subsequent diet selection analysis. Fig. 1 shows the mean proportion of food $\mathrm{H}$ selected from 11.00 to 17.00 hours by sheep initially offered H or L between 09.00 and 11.00 hours. Overall, the preference for the $\mathrm{H}$ food was significantly greater in sheep initially offered $\mathrm{L}$ than in sheep initially offered $\mathrm{H}(P<0 \cdot 001)$. This difference was significant in all of the $2 \mathrm{~h}$ time intervals considered, but its size diminished with time. The mean proportion of $\mathrm{H}$ selected from 11.00 to 17.00 hours was 0.544 and 0.873 (SED 0.0280 ) $\mathrm{g}$ $\mathrm{H} / \mathrm{g}$ TFI for sheep previously offered food $\mathrm{H}$ or food $\mathrm{L}$ between 09.00 and 11.00 hours respectively. 
Table 5. Total food intake during each $2 \mathrm{~h}$ interval and daily, and the daily metabolizable energy (ME) intake of sheep offered one of the basal

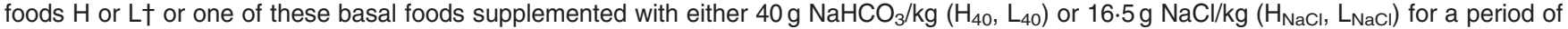
$2 \mathrm{~h}$ from 09.00 to 11.00 hours, followed by a choice between the basal foods $\mathrm{H}$ and $\mathrm{L}$ from 11.00 to 17.00 hours (test $\mathrm{C}$ ) $\ddagger$

(Mean values for five sheep per group)

\begin{tabular}{|c|c|c|c|c|c|c|c|c|c|}
\hline & \multicolumn{6}{|c|}{ Treatment } & \multirow[b]{2}{*}{ SED } & \multicolumn{2}{|c|}{ Statistical significance of: } \\
\hline & $\mathrm{H}$ & $\mathrm{H}_{40}$ & $\mathrm{H}_{\mathrm{NaCl}}$ & $\mathrm{L}$ & $\mathrm{L}_{40}$ & $\mathrm{~L}_{\mathrm{NaCl}}$ & & ED & Supplementation§ \\
\hline \multicolumn{10}{|l|}{ Treatment food $(\mathrm{g})$} \\
\hline $09.00-11.00$ hours & 539 & 610 & 472 & 718 & 663 & 607 & $59 \cdot 2$ & $\star \star *$ & NS \\
\hline \multicolumn{10}{|l|}{ Choice period $(\mathrm{g})$} \\
\hline $11.00-13.00$ hours & 342 & 384 & 471 & 440 & 511 & 469 & $74 \cdot 8$ & NS & NS \\
\hline $13.00-15.00$ hours & 299 & 327 & 363 & 315 & 293 & 287 & 39.9 & NS & NS \\
\hline $15.00-17.00$ hours & 329 & 366 & 446 & 393 & 362 & 361 & $59 \cdot 1$ & NS & NS \\
\hline $11.00-17.00$ hours & 970 & 1077 & 1280 & 1147 & 1166 & 1117 & $146 \cdot 1$ & NS & NS \\
\hline Daily food intake $(\mathrm{g} / \mathrm{d})$ & 1509 & 1687 & 1751 & 1865 & 1829 & 1724 & $168 \cdot 7$ & NS & NS \\
\hline Daily ME intake (MJ/d) & $15 \cdot 3$ & $17 \cdot 2$ & $17 \cdot 3$ & 17.5 & $17 \cdot 6$ & $16 \cdot 7$ & 1.50 & NS & NS \\
\hline
\end{tabular}

ED, energy density.

†Food $\mathrm{H} 11 \mathrm{MJ} / \mathrm{kg}$, food $\mathrm{L} 8 \mathrm{MJ} / \mathrm{kg}$ (for details of foods, see Table 1).

¥For details of procedures, see p. 83.

$\S$ The interaction between ED and supplementation was NS.

${ }^{* *} P<0.01$.

There was no significant effect of previous food offered, from 09.00 to 11.00 hours, on live weight gain or food conversion efficiency. The live-weight gains and food conversion efficiency for sheep initially offered $\mathrm{H}$ or $\mathrm{L}$ between 09.00 and 11.00 hours were 258 and 293 (SED 18.2) g/d and 158 and 163 (SED 8.5) g gained/kg food respectively.

\section{Discussion}

Diets selected by ruminant animals in a number of previous experiments (e.g. Newman et al. 1994; Parsons et al. 1994; Cooper et al. 1995, 1996; Concha \& Nicol, 2000) have not been consistent with the assumption of the optimal foraging theory, as the animals did not maximize their shortterm rate of energy intake. The current experiment was expected to provide some insight into why ruminant animals, in the short-term, select a diet with a lower ME content than available.

It has been suggested that ruminant animals might select a diet in an attempt to maintain their rumen environment within a certain physiological range (Parsons et al. 1994; Cooper et al. 1995, 1996). It could therefore be hypothesized that ruminant animals include a large proportion of the lower-ED food in their diet, and hence do not maximize their short-term energy intake rates, in order to dilute the disruptive effects of the high-ED food when they are given a choice. Ruminant animals can be seen as having to make a trade-off in their diet selection. The benefits of selecting a higher-ED food, and hence meeting their energy requirements, need to be set against the cost of

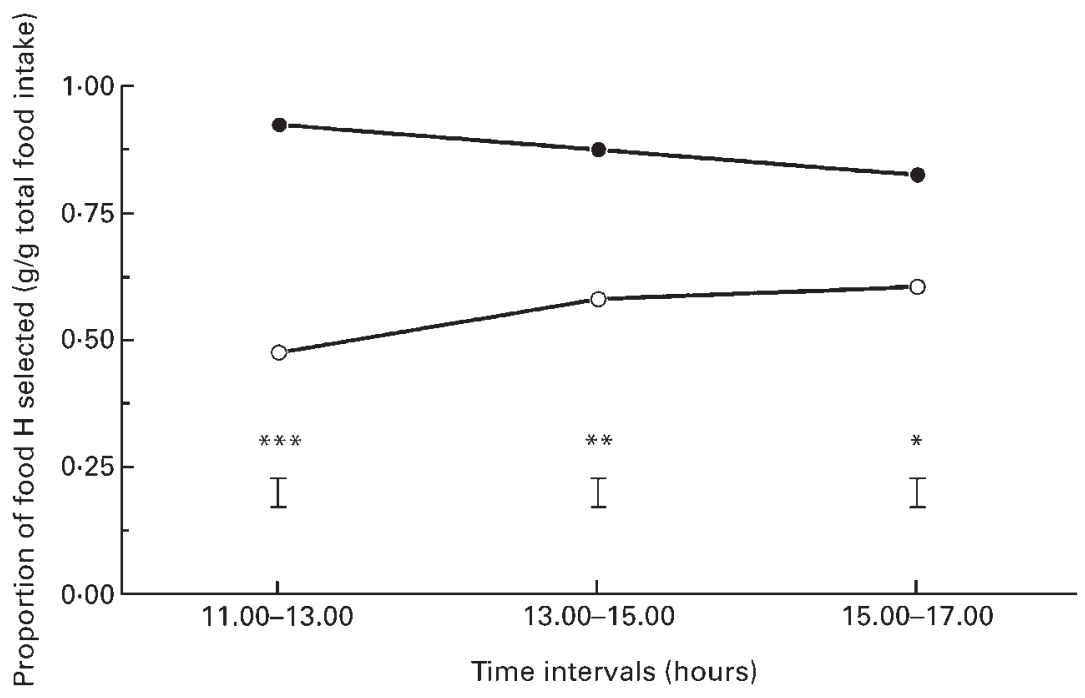

Fig. 1. The proportion of food $\mathrm{H}$ selected $(\mathrm{g} / \mathrm{g})$ by sheep offered a choice between two foods $\mathrm{H}$ and $\mathrm{L}$ that differ mainly in energy density from 11.00 to 17.00 hours. The sheep had previously been offered one of $\mathrm{H}(\mathrm{O})$ or $\mathrm{L}(\bullet)$ alone for a period of $2 \mathrm{~h}$ immediately prior to the choice of foods being offerd. Food $\mathrm{H} 11 \mathrm{MJ} / \mathrm{kg}$, food $\mathrm{L} 8 \mathrm{MJ} / \mathrm{kg}$. For details of foods and procedures see Table 1 and p. 83. Values are means for fifteen sheep per group. ${ }^{*} P<0.05,{ }^{* *} P<0.01,{ }^{* *} P<0.001$. 
disrupting the rumen environment (Kyriazakis et al. 1999). Short-term modifications in diet selection could therefore be seen as aiming first, to prevent further disruption to the rumen environment after a 'disruptive' food has already been consumed, and second, to return the conditions in the rumen to within an acceptable range as soon as possible (Kyriazakis, 1997).

The objective of the present experiment was to determine the effect of consumption of foods that differ in ED and/or $\mathrm{NaHCO}_{3}$ supplementation, hence differing in their potential effects on the rumen environment, on subsequent diet selection in sheep. Two important preliminary tests (A and $\mathrm{B}$ ) were needed before moving to the main objective.

\section{Test A}

During this test, sheep offered a choice of foods continuously did not predominantly select the high-ED food as would have been predicted by the optimal foraging theory (Stephens \& Krebs, 1986), but selected a diet that did not differ significantly from random and which had a considerable proportion of L. Restricting the time that food was offered to $8 \mathrm{~h} / \mathrm{d}$ produced a non-random diet selection with the sheep showing a marked preference for L. The proportion of $\mathrm{H}$ in the diet selected increased from the first week to the second week of this test for both groups. The increase in the proportion of $\mathrm{H}$ selected could have been due to the adaptation of the ruminant to the products of fermentation associated with the foods offered and the adaptation of the microbes to both the foods offered and the new rumen environment (Mackie et al. 1978).

The results from this test contradict the rate maximization assumption of the optimal foraging theory (Stephens \& Krebs, 1986). They are in agreement with the hypothesis that sheep select a diet consistent with the idea of a tradeoff and balance the benefits of selecting the higher ED food against the cost of disrupting the rumen environment (Cooper et al. 1995, 1996; Faverdin, 1999; Kyriazakis et al. 1999). The direction of the change in diet selection, as time availability of the foods offered as a choice was reduced, is particularly in support of this.

\section{Test $B$}

Sheep on H, which was used as a treatment food from 09.00 to 11.00 hours had a significantly lower intake than any other group of sheep. At 11.00 hours this group of sheep also had the lowest recorded rumen $\mathrm{pH}$. This suggests that the $\mathrm{H}$ food was indeed disruptive to the rumen environment and could potentially cause sheep to limit the intake of this food and increase the intake of an alternative food when given a choice (Phy \& Provenza, $1998 a, b)$. The qualities of food $\mathrm{H}$ therefore met the requirements of this experiment.

Osbourn et al. (1970) and Erdman (1988) proposed that supplementing a high-ED food with $\mathrm{NaHCO}_{3}$ would increase food intake through an increase in rumen $\mathrm{pH}$. This was found to be the case during the $2 \mathrm{~h}$ period that the treatment food was offered, with the exception of sheep offered foods supplemented with $80 \mathrm{~g} \mathrm{NaHCO}_{3} / \mathrm{kg}$.
However, mineral salts cause an increase in osmolality when consumed (Hart \& Polan, 1984), which in turn has been demonstrated to have an adverse effect on intake (Carter \& Grovum, 1988, 1990). The reduced food intake of sheep on the treatment supplemented with $80 \mathrm{~g}$ $\mathrm{NaHCO}_{3} / \mathrm{kg}$ can thus be explained by an increased osmolality effect as proposed by Carter \& Grovum $(1988,1990)$.

The addition of $40 \mathrm{~g} \mathrm{NaHCO}_{3} / \mathrm{kg}$ was superior to all other $\mathrm{NaHCO}_{3}$ concentrations as judged by the combined effects on food intake, $\mathrm{pH}$ and acid buffering capacity of 11.00 hours and hence used for test $\mathrm{C}$. It can, however, be seen that $40 \mathrm{~g} \mathrm{NaHCO}_{3} / \mathrm{kg}$ was not as effective as $\mathrm{L}$ in decreasing the fall in rumen $\mathrm{pH}$ and increasing subsequent intake of food $\mathrm{H}$. Sheep offered food $\mathrm{L}$ for $2 \mathrm{~h}$ managed to consume subsequently significantly more $\mathrm{H}$ food and significantly more ME daily, than any other group. This suggests that the magnitude of disruption was less for sheep offered food $\mathrm{L}$ and that the beneficial effects of food $\mathrm{L}$ on the rumen environment were carried over for a longer period than those of any other treatment.

\section{Test $C$}

It was hypothesized that ruminant animals would select a diet as a result of a trade-off between the benefits of maximizing energy intake against the costs of disrupting the rumen environment (Parsons et al. 1994; Cooper et al. 1995, 1996). The objective of test $C$ was to determine the effect of consumption of foods that differ in ED and/ or $\mathrm{NaHCO}_{3}$ on subsequent diet selection in sheep. It was expected that sheep initially offered the disruptive $\mathrm{H}$ food for a short period of time would need to include a larger proportion of $\mathrm{L}$ in their subsequent diet to return conditions in the rumen to within an acceptable range as soon as possible. However, sheep initially offered the L food would not have experienced the same disruption to the rumen environment and therefore would not require as large a proportion of food $\mathrm{L}$ in their subsequent diet resulting in an increased $\mathrm{ME}$ intake. During test $\mathrm{B}$ $\mathrm{NaHCO}_{3}$ supplementation had reduced the disruptive effects of the pre-offered $\mathrm{H}$ food by reducing the fall in rumen $\mathrm{pH}$ (Ha et al. 1983; Hart \& Polan, 1984). However, $40 \mathrm{~g} \mathrm{NaHCO}_{3} / \mathrm{kg}$ was not as effective as food $\mathrm{L}$ in reducing the disruption of the rumen environment. Therefore, it was expected that the subsequent proportion of food $\mathrm{L}$ selected to reduce the disruption caused by the pre-offered $\mathrm{H}$ food supplemented with $\mathrm{NaHCO}_{3}$ would lie between that selected by sheep offered either $\mathrm{H}$ or $\mathrm{L}$ unsupplemented as a treatment food.

In agreement with this hypothesis, sheep initially offered the disruptive $\mathrm{H}$ food selected a greater proportion of $\mathrm{L}$ during the subsequent period compared with those initially offered L. It was found during test B that the consumption of food $\mathrm{H}$ resulted in a low rumen $\mathrm{pH}$ and a decrease in subsequent food intake. Therefore, it is likely that sheep initially offered $\mathrm{H}$ needed to include a large proportion of $\mathrm{L}$ in their diet when offered a choice. On the other hand, food $\mathrm{L}$, when consumed alone, did not disrupt the rumen to the same degree as food $\mathrm{H}$ (test B) due to its predicted slow fermentation rate. Therefore food L would dilute the subsequent disruptive effects of the $\mathrm{H}$ food as 
it was consumed and buffer the by-products of fermentation (McBurney et al. 1983; Jasaitis et al. 1987). As the rumen environment was not disrupted to a large degree, a low proportion of $\mathrm{L}$ was required during the subsequent diet selection resulting in an increased $\mathrm{ME}$ intake.

Supplementing food $\mathrm{H}$ with $40 \mathrm{~g} \mathrm{NaHCO} / \mathrm{kg}$ did not result in a change in subsequent diet selection as expected. It was previously suggested that the degree to which the animal alters subsequent diet selection lies along a continuum so that even small changes in the internal environment would lead to small changes in subsequent diet selection (Provenza, 1995). However, the fact that adding $\mathrm{NaHCO}_{3}$ to $\mathrm{H}$ did not result in a decrease in the proportion of food $\mathrm{L}$ selected during the subsequent diet selected, compared with sheep offered $\mathrm{H}$ unsupplemented, could be seen to disagree with this suggestion. It is unlikely that ruminant animals will try to keep their rumen environment at a constant state where small deviations in the rumen environment warrant modifications in the diet selected to correct the deviations. It is more likely that there will be a range of conditions that the animal will tolerate (e.g. Cooper et al. 1995; Kyriazakis \& Oldham, 1997). Should changes to the rumen environment exceed these 'tolerance' limits, modification to the diet selected could be expected. Therefore, larger rather than smaller changes in the rumen environment should be expected to alter subsequent diet selection (Kyriazakis et al. 1999). The fact that subsequent diet selection was not significantly altered when food $\mathrm{H}$ supplemented with $\mathrm{NaHCO}_{3}$ was offered as a treatment food compared with $\mathrm{H}$ supplemented, yet offering food L, an even less disruptive food, significantly altered subsequent diet selection, supports this hypothesis.

An animal, given free and continuous access to a single food over a period of time, can regulate its energy intake only by eating more or less of the food offered (Kyriazakis \& Oldham, 1993). During test B, food H was shown to be disruptive and as the sheep were unable to alter their diet, as no other food was offered, food intake and consequently daily ME intake were decreased. However, during test $\mathrm{C}$, a choice of foods was subsequently offered and sheep were able to modify their subsequent diet selection and achieve the same daily ME intake regardless of the treatment food that they were offered previously. The progressive increase and decrease in the proportion of food $\mathrm{H}$ selected with time over the choice period, by sheep initially offered $\mathrm{H}$ or $\mathrm{L}$ respectively, is in support of this.

In conclusion, the sheep in this experiment appear to select a diet in agreement with the hypothesis that ruminant animals are faced with making a trade-off between the benefits of increasing energy intake against the costs of disrupting the rumen environment. The diet selected would be expected first, to prevent further disruption to the rumen environment, which could be detrimental due for example to acidosis, and second, to return the conditions in the rumen to within the accepted range as soon as possible (Kyriazakis, 1997). The results from the present experiment are also in agreement with the idea that changes within the rumen of 'large' rather than 'small' magnitude, due to the consumption of a disruptive food, will alter subsequent diet selection by sheep (Kyriazakis \& Day,
1998; Kyriazakis et al. 1999). Ruminant animals make short-term adjustments in their diet selection in response to large changes in their current internal state and these enable them to meet their energy and nutrient requirements in the longer timescale, such as a day.

\section{Acknowledgements}

The experimental work was supported by BBSRC and the Scottish Executive, Environment and Rural Affairs Department. S. James acknowledges the support of BBSRC for a studentship. We are grateful to Messrs D.H. Anderson and T. McHale for their expert technical assistance and to Dr M. Lewis for helping us with the formulation of the foods. We thank Mr D. Allcroft (BIOSS) for statistical advice.

\section{References}

Agricultural and Food Research Council (1993) Energy and Protein Requirements of Ruminants. Wallingford: CAB International.

Belovsky GE (1978) Diet optimization in a generalist herbivore: The moose. Theoretical Population Biology 14, 105-134.

Belovsky GE \& Schmitz OJ (1994) Plant defenses and optimal foraging by mammalian herbivores. Journal of Mammalogy 75, 816-832.

Carter RR \& Grovum WL (1988) Observations on how sodium chloride loading of the rumen depressed food intake in sheep. Proceedings of the Nutrition Society 47, 155A.

Carter RR \& Grovum WL (1990) Factors affecting the voluntary intake of food by sheep. 5. The inhibitory effect of hypertonicity in the rumen. British Journal of Nutrition 64, 285-299.

Charnov EL (1975) Optimal foraging, the marginal value theorem. Theoretical Population Biology 9, 129-136.

Concha MA \& Nicol AM (2000) Selection by sheep and goats for perennial ryegrass and white clover offered over a range of sward height contrasts. Grass and Forage Science 55, 47-58.

Cooper SDB, Kyriazakis I \& Nolan JV (1995) Diet selection in sheep - The role of the rumen environment in the selection of a diet from two feeds that differ in their energy density. British Journal of Nutrition 74, 35-54.

Cooper SDB, Kyriazakis I \& Oldham JD (1994) The effect of late pregnancy on the diet selection made by ewes. Livestock Production Science 40, 263-275.

Cooper SDB, Kyriazakis I \& Oldham JD (1996) The effects of physical form of feed, carbohydrate sources, and inclusion of sodium bicarbonate on the diet selection of sheep. Journal of Animal Science 74, 1240-1251.

Erdman RA (1988) Dietary buffering requirements of the lactating dairy cow: A review. Journal of Dairy Science 71, 3246-3266.

Faverdin P (1999) The effect of nutrients on feed intake in ruminants. Proceedings of the Nutrition Society 58, 523-531.

Ha JA, Emerick RJ \& Embry LB (1983) In vitro effect of pH variations on rumen fermentation and in vivo effects of buffers in lambs before and after adaptation to high concentrate diets. Journal of Animal Science 56, 698-706.

Hart SP \& Polan CE (1984) Effects of sodium bicarbonate and disodium phosphate on animal performance, ruminal metabolism, digestion, and rate of passage in ruminating calves. Journal of Dairy Science 67, 2356-2368.

Illius AW, Clark DA \& Hodgson J (1992) Discrimination and patch choice by sheep grazing grass-clover swards. Journal of Animal Ecology 61, 183-194. 
Jasaitis DK, Wohlt JE \& Evans JL (1987) Influence of feed ion content on buffering capacity of ruminant feedstuffs in vitro. Journal of Dairy Science 70, 1397-1403.

Kaufman W (1976) Influence of the composition of the ration and the feeding frequency on $\mathrm{pH}$ regulation in the rumen and on feed intake. Livestock Production Science 3, 103-114.

Kenney PA \& Black JL (1984) Factors affecting diet selection in sheep. I. Potential intake rate and acceptability of feed. Australian Journal of Agricultural Research 35, 551-563.

Kyriazakis I (1997) The Nutritional Choices of Farm Animals: To Eat or What To Eat? In Animal Choices pp. 55-65 [JM Forbes, TLJ Lawrence, RG Rodway and MA Varley, editors]. Edinburgh: British Society of Animal Science.

Kyriazakis I \& Day JEL (1998) Does the study of feeding behaviour benefit from a teleonomic framework? Nutrition Research Reviews 11, 223-229.

Kyriazakis I \& Oldham JD (1993) Diet selection in sheep: the ability of growing lambs to select a diet that meets their crude protein (nitrogen $\times 6.25$ ) requirements. British Journal of Nutrition 69, 617-629.

Kyriazakis I \& Oldham JD (1997) Food intake and diet selection in sheep: the effect of manipulating the rates of digestion of carbohydrates and proteins of the foods offered as a choice. British Journal of Nutrition 77, 243-254.

Kyriazakis I, Tolkamp BJ \& Emmans GC (1999) Diet selection and animal state: An integrative framework. Proceedings of the Nutrition Society 58, 765-772.

McBurney MI, Van Soest PJ \& Chase LE (1983) Cation exchange capacity and buffering capacity of neutral-detergent fibres. Journal of the Science of Food and Agriculture 34, 910-916.

Mackie RI, Gilchrist MC, Robberts AM, Hannah PE \& Schwartz HM (1978) Microbial and chemical changes in the rumen during the stepwise adaptation of sheep to high concentrate diets. Journal of Agricultural Science, Cambridge 90 241-254.

Ministry of Agriculture, Fisheries and Food (1990) UK Tables of Nutritive Value and Chemical Composition of Feeding Stuffs [DI Givens and Angela R Moss, editors]. Aberdeen: Rowett Research Services Ltd.
Ministry of Agriculture, Fisheries and Food (1993) The determination of neutral detergent (plus amylase) fibre (NDF) of feeding stuffs, appendix III. In Prediction of the Energy Values of Compound Feeding Stuffs for Farm Animals: Summary of Recommendations of a Working Party Sponsored by the Ministry of Agriculture, Fisheries and Food. London: MAFF Publications.

Newman JA, Penning PD, Parsons AJ, Harvey A \& Orr RJ (1994) Fasting affects intake behavior and diet preference of grazing sheep. Animal Behavior 47, 185-193.

Osbourn DF, Terry RA, Cammell BB \& Outen GE (1970) Some effects of feeding supplements of maize meal and sodium bicarbonate upon the digestion of forage cellulose by sheep. Proceedings of the Nutrition Society 29, 12A.

Owens FN, Secrist DS, Hill WJ \& Gill DR (1998) Acidosis in cattle: A review. Journal of Animal Science 76, 275-286.

Parsons AJ, Newman JA, Penning PD, Harvey A \& Orr RJ (1994) Diet preference of sheep: effects of recent diet, physiological state and species abundance. Journal of Animal Ecology 63, 465-478.

Phy TS \& Provenza FD (1998a) Eating barley too frequently or in excess decreases lambs' preference for barley but sodium bicarbonate and lasalocid attenuate the response. Journal of Animal Science 76, 1578-1583.

Phy TS \& Provenza FD (1998b) Sheep fed grain prefer foods and solutions that attenuate acidosis. Journal of Animal Science 76, 954-960.

Provenza FD (1995) Postingestive feedback as an elementary determinant of food preference and intake in ruminants. Journal of Range Management 48, 2-17.

Russell JB, Sharp WM \& Baldwin RL (1979) The effect of pH on maximum bacterial growth rate and its possible role as a determinant of bacterial composition in the rumen. Journal of Animal Science 48, 251-255.

Stephens DW \& Krebs JR (1986) Foraging Theory. Princeton, NJ: Princeton University Press.

Van Wieren SE (1996) Do large herbivores select a diet that maximizes short-term energy intake rate? Forest Ecology and Management 88, 149-156. 